\title{
Ozone and Products of Ozonation in Medical Use
}

\author{
Marta Radzimierska* and Krzysztof Śmigielski \\ Faculty of Biotechnology and Food Sciences, Poland
}

*Corresponding author: Marta Radzimierska, Faculty of Biotechnology and Food Sciences, Institute of General Food Chemistry, Poland

\begin{tabular}{|c|c|}
\hline ARTICLE INFO & ABSTRACT \\
\hline Received: 粗 April 12, 2019 & Ozone, or trioxygen, is an allotrope of oxygen occurring in the Earth's stratosphere. \\
\hline Published: 蔧 April 17, 2019 & $\begin{array}{l}\text { Because of unique properties, this pale blue gas is applied in many sectors of medicine and } \\
\text { industry. Trioxygen is used as a powerful oxidant in chemical reactions, for production of }\end{array}$ \\
\hline $\begin{array}{l}\text { Citation: Marta Radzimierska, } \\
\text { Krzysztof Śmigielski. Ozone and } \\
\text { Products of Ozonation in Medical } \\
\text { Use. Biomed J Sci \& Tech Res 17(1)- }\end{array}$ & $\begin{array}{l}\text { ozonized oils and water, and in various branches of medicine. Medicinal applications of } \\
\text { ozone, which began in XX century, are particularly interesting because they result from } \\
\text { the anti-microbial activity of ozone. Currently, ozone is used mainly in surgery, dentistry } \\
\text { and orthopedics. }\end{array}$ \\
\hline
\end{tabular}

Keywords: Ozone in Medicine; Ozonized Oil; Ozone in Dentistry; Ozone in Surgery

\section{Introduction}

Ozone has been increasingly used in medicine due to its disinfecting properties, enabling, among others, sterilization of equipment before surgery. Another promising application is an ozone therapy, which became a conventional method of treatment in many countries as it is safe for patients [1-4]. Very strong antimicrobial properties of ozone cause that it helps in antibiotic therapies, treatment of wounds and ulcers, and after surgeries. The main drawback of ozone is its limited stability in the mixture with air. To solve this problem and extend the half-life of this compound, it is used in the form of either ozone-oxygen mixture or ozonized water in dentistry and other fields of medicine, e.g. dermatology, orthopedics, traumatology and surgery. Another solution is based on the use of ozonized oils. The ozonation of water and oils is conducted using the same method, it means by passing the gaseous ozone through the liquid. Noteworthy, the ozone's half-life in oils is many times longer comparing to its solutions in water. Therefore, physicians prefer to use the ozonized oils [1,5-6].

\section{Discussion}

In dentistry, specialized ozone generators are used to apply ozone directly to the desired site. In periodontology, gingivitis, periodontitis, oral candidiasis, aphthae, and herpes are treated using the trioxygen. In conservative dentistry, the anti-microbial properties of ozone enable to treat caries and tooth pulp infections. In dental implantology, ozone is used to treat infections and poorly healing wounds [1,7]. The effect of disinfectants, such as gaseous ozone and ozonated water, was compared in in vitro studies, involving such microorganisms as: Enterococcus faecalis, Peptostreptococcus micros, Pseudomonas aeruginosa, and Candida albicans, which reflect the infection of the dental root. The microorganisms were used in the form of either biofilms or suspensions [8]. In the case of cell suspensions, the ozonized water containing up to $5 \mathrm{\mu gO}_{3} / \mathrm{ml}$ caused the significant reduction in the count of microbial cells, while the gaseous ozone was not effective as it did not reduce the count. In the case of microbial biofilms, the potency of ozone either in the gaseous form or dissolved in water depended on its concentration, microbial species, and the time of exposure.

The significant reduction of the number of microbial cells was observed after $1 \mathrm{~min}$ treatment at the high concentration of gaseous ozone. Also ozonized water containing $20 \mu \mathrm{gO} 3 / \mathrm{ml}$ reduced the number of microbial cells nearly to zero [1,9]. The literature reports describing the use of ozone therapy in surgery, for the treatment of wound infections and ulcers, are scarce [1]. This is surprising because the first report about the positive, anti-microbial effect of ozone, which was used to prevent complications resulting from the open bone fractures during the war, was published in 1916 by Major Stoker [10]. An increasing number of medical reports provides evidence of the positive effects of ozone therapy in the treatment and prevention of postoperative complications in orthopedics and traumatology of motor organs.

They are associated with the treatment of chronic, long-term non-healing wounds, soft tissue ulcerations, bone infections of various etiologies, fistulas, complex diseases, which include, among 
others, diabetic foot syndrome or trophic foot ulcers, ischemic post-traumatic states with soft tissue injuries. In addition, the use of ozone proves to be very effective in the prevention of nosocomial infections after reconstructive orthopedic surgery, soft tissue and skin defects (significantly facilitates the preparation of the graft base) or treatment of infected post-traumatic wounds, especially in the case of open fractures. Peritonitis and purulent pelvic inflammations have also been treated with ozone therapy. Ozonized liquids, such as water or oil, are already used externally and their effectiveness is very high. These formulations are particularly wellsuited for the treatment of leg ulcers related to post-thrombotic syndromes. Not only wound healing is much faster when supported by the ozone therapy, but also purulent exudates from wounds are reduced, which significantly increases the comfort of the patient $[1,6,11-18]$. Research conducted by Białoszewski and others [12] demonstrated the effectiveness of ozone therapy as a method of combined treatment in patients after trauma and musculoskeletal disorders. The combined therapy is based on the traditional treatment supported by ozone therapy. Due to the increasingly popular antibiotic therapy and rapidly increasing drug resistance of microorganisms, it is necessary to find new methods enabling inactivation of microbes. Ozone, in appropriate concentrations, becomes the answer to the problem of bacterial resistance. So far, the vast majority of microorganisms do not show ozone resistance. The results of research carried out by Białoszewski and others are very promising as the ozone therapy significantly reduced the time of hospitalization, the use of antibiotics, and the number of purulent complications. According to physicians, the use of drainage with ozone guarantees more effective inactivation of microorganisms comparing to commercially available antibiotics, is much cheaper and should be used as a conventional treatment method. Noteworthy, even in the case of secondary bone infections, the combined treatment including the ozone therapy brings about satisfactory results [12]. In dermatology and aesthetic medicine, ozone is a perfect tool against skin eczema, acne, lichen or cutaneous mycosis. Skin after burn also regenerates much faster when treated with preparations containing ozone [6,19-20].

Studies on application of ozone therapy against vaginal mucosal infections in gynecology have been scarce despite few deaths caused by, among others, the toxic shock syndrome (TSS) resulting from the inappropriate use of tampons by women. Besides, many women suffer from the fungal, viral, and bacterial infections caused by such pathogens as Neisseria gonorrhoeae, Trichomonas vaginalis, Candida albicans, Chlamidia trachomatis, and Herpes virus type-II (HV-II), HIV and HPV. These microorganisms, among others, increase the risk of cervical cancer, which is becoming an often-encountered cancer among women. Unfortunately, a typical treatment, which includes antibiotic therapy, is expensive, has many side effects, and what's more, does not cause the desired effects when the microbial strain develops resistance to a given medicine. The use of ozone therapy in the treatment is still at the stage of research. Ozone therapy proved to be excellent in the case of elimination of recurring infections caused by the HV-II virus. The overnight application of either ozonized water or oils caused the desired effects in combating vaginal infections while the prolonged use enabled to eliminate all gynecological problems because of elimination of the pathogenic microflora from the reproductive system. In addition, none of the above-mentioned pathogenic microorganisms showed the ozone resistance. Also the creams containing ozone oils can bring about the desired effects in combating intimate infections, accelerate micro-circulation, reduce swelling, minimize pruritus and bring relief when used 3-4 times a day $[6,21-23]$.

\section{Conclusion}

Despite many concerns about possible undesired carcinogenic or toxic effect of ozone therapy, the literature reports provide evidence that treatments carried out at appropriate ozone concentrations and appropriate exposure time, have positive therapeutic effects and support other therapies. Furthermore, microbes do not show any resistance to ozone [5]. Its greatest advantages include, first of all, the wide spectrum of antimicrobial activity as it kills bacteria, fungi and viruses. In addition, it improves the tissue oxygenation by stimulating the metabolism of erythrocytes, increasing oxygen transport by hemoglobin, improving the transmembrane oxygen flow, and reducing platelet aggregation. This in turn activates the immune system of organism, which enhances the immunity, both general and local, and helps to achieve the oxidative balance $[1,5,12,19]$.

\section{References}

1. Białoszewski D, Bocian E, Tyski S (2012) Ozonoterapia oraz zastosowanie ozonu w dezynfekcji. Postępy Mikrobiologii 51(3): 177-184.

2. Antoszewski Z, Skowron J, Wachowski J, Urbańczyk L, Kulej J (2000) Krótka historia zastosowania ozonoterapii w polskiej medycynie oraz techniki stosowania ozonu u chorych poparzonych. Medycyna 23-24.

3. Bocci V (2006) Is it true that ozon is always toxic? The end of a dogma. Toxicol Appl Pharmacol 216: 493-504.

4. Ikonomidis S, Tsaousis P, Fyntanis A, Iliakis EM (2005) New data regarding the use of ozone therapy in the former Soviet Union countries. Rivista Italiana di Ossigeno- Ozonoterapia 4: 40-43.

5. Valacchi G, Fortino V, Bocci V (2005) The dual action of ozone on the skin. BJD 153 (6): 1096-1100.

6. Travagli V, Zanardi I, Valacchi G, Bocci V (2010) Ozone and ozonated oils in skin diseases: a review. Mediat Inflam: 610418.

7. Iwanek P (2007) Biologiczne podstawy działania ozonu na florę jamy ustnej. Annales Academiae Medicae Stetinensis 53 (4): 41-44.

8. Huth KC, Quirling M, Maier S, Kamereck K, Alkhayer M, et al. (2009) Efectiveness of ozone against endontopathogenic microorganisms in a root canal biofilm model. Int Endod J 42: 3-13.

9. Bocci V (1999) Biological and clinical effects of ozone. Has ozone therapy a future in medicine? Br J Biomed Sci 56(4): 270-279.

10. Stoker G (1916) The surgical uses of ozone. Lancet II (21): 712.

11. Białoszewski D,Bocian E, Bukowska B, Czajkowska M, Sokół Leszczyńska B, et al. (2010) Antimicrobial activity of ozonated water. Med Sci Monitor 16(9): 71-75.

12. Białoszewski D, Kowalewski M (2001) Przydatność miejscowych, głębokich insuflacji mieszaniną ozonowo- tlenową w profilaktyce i leczeniu zakażeń w obrębie narządów ruchu. Ortop Traum Rehab 3(4): 552-556.

13. Bialoszewski D, Nowak P, Michalski P (2000) Przydatność terapii ozonem w leczeniu przewlekłych i pourazowych patologii w obrębie narządów ruchu. Ortop Traum Rehab 4: 47-49. 
14. Kim HS, Noh SU, Han YW, Kim KM, Kang H, et al. (2009) Therapeutic effects of typical aplication of ozone on acute cutaneous wound healing J Korean Med Sci 24(3): 368-374.

15. Lelianov AD, Budrin VA, Novikov AS, Guseva ED, Nesterov AA, et al. (2007) Optimization of the treatment of stomach ulcer in patients subjected to perforated gastroduodental ulcer closure. Eksp Klin Gastroenterol 5: 8185.

16. Shah P, Shyam AK, Shah S (2011) Adjuvanlt combined ozone therapy for extensive wound over tibia. Indian J Orthop 45(4): 376-379.

17. Ventskovski ABM, Zhegulovich VG, Marchenko VV (2007) Surgical treatment of acute purulent inflammatory processes in the pelvic area. Lik Sprava 5(6): 76-82.

18. Wainstein J, Feldbrin Z, Boaz M, Harman Boehm I (2011) Efficacy of ozone- oxygen therapy for the treatment of diabetic foot ulcers. Diabetes Technol Ther 13(12): 1255-1260.

\section{ISSN: 2574-1241}

DOI: $10.26717 /$ BJSTR.2019.17.002959

Marta Radzimierska. Biomed J Sci \& Tech Res

(C) (i) This work is licensed under Creative

Submission Link: https://biomedres.us/submit-manuscript.php
19. Sadowska Pietrzak J (2013) Zastosowanie ozonu w kosmetologii i medycynie estetycznej. Kosmet Estet 3 (2): 169-172.

20. Bocci AV (2006) Scientific and medical aspects of ozone therapy, State of the art. Arch Med Res 37(4): 425-435.

21. Bocci V, Borelli E, Travagli V, Zanardi I (2009) The ozone paradox: ozone is a strong oxidant as well as a medical drug. Med Res Rev 29(4): 646682.

22. Menèndez S, Re L, Falcon F, MB Argote, et al. (2008) Safety of topical Oleozon $\mathbb{R}$ in the treatment of tinea pedis: phase IV clinical trial. Int Jour of Ozone Ther 7: 55-59.

23. Menèndez S, Falcon F, Maqueira $Y$ (2011) Therapeutic efficacy of

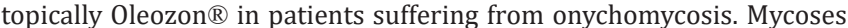
54(5): 272-277.

$\begin{array}{ll}\text { BIOMEDICAL } & \text { Assets of Publishing with us } \\ \text { RESEARCHES } & \text { - Global archiving of articles } \\ & \text { - Immediate, unrestricted online access } \\ \end{array}$

